SUPPLEMENT No. 1

BIOSOCIAL ASPECTS OF RACE

Edited by G. A. HARRISON and J. PEEL

202 pp. $£ 3.00$ (U.S.\$8.50)

List of contents and authors:

General Introduction by A. S. Parkes. Limitations

to Genetic Comparison of Populations by

J. M. Thoday. Natural Selection and Population

Diversity by A. C. Allison. Ethnic, Caste and

Genetic miscegenation by F.S. Hulse. Race,

Genetics and Growth by D. F. Roberts. Racial and Inter-racial Differences in Work Capacity by

K. Lange Andersen. Ethnic Differences in Sensory Perception by Hans Kalmus. Contributions of Ability and Attainment Testing in Africa to a General Theory of Intellect by S. H. Irvine. Comment. Olympiad Festival of the Nations, 1936 by Hans Kalmus. Population Prospects for Regions of the World by Wallis Taylor. Differential Fertility Among Immigrants to England and Wales and Some Implications for Population Projections by Jean Thompson. The Galton Lecture 1968: The Race Concept in Human Biology by G. Ainsworth Harrison. Race as a Social Category by John Rex. Race, Pluralism and Nationalism in the British Caribbean by Ivar Oxaal. The Role of the Settlement Area in British Race Relations by M. H. Lyon. Cognitive Aspects of Prejudice by Henri Tajfel.

\title{
SUPPLEMENT No. 2
} BIOSOCIAL ASPECTS OF SEX Edited by G. A. HARRISON and J. PEEL 164 pp. £2.50 (U.S.\$7.00)

List of contents and authors:

General Introduction by A. S. Parkes.

Cytogenetics and Sex Determination in Man and Animals by C. E. Ford. Sex Differences at Puberty by W. A. Marshall. Aspects of Homosexuality by D. J. West. The Search for Genetic Variability of the Sex Ratio by A. W. F. Edwards. Factors Affecting the Sex Ratio in Large Populations by M. S. Teitelbaum. Sex Differences in Age at Marriage by P. R. Cox. The Social Images of Man and Woman by Rosemary Firth. A Comparison of the Academic Performance of Male and Female Students in Schools and Universities by R. R. Dale. The Comparative Employability of Men and Women in Different Industries by B. T. Davies. The Galton Lecture 1969: Women in Academic Life by Kathleen M. Kenyon. Sex Differences in Divorce Behaviour by Robert Chester. Sex, Crime and Society by Frances Heidensohn. Sex Differences in the Neurotic Reactions of the Aged by

K. Bergmann. Which is the Weaker Sex? by D. M. Potts. 


\section{BIOSOCIAL ASPECTS OF HUMAN FERTILITY \\ Edited by ALAN S. PARKES, JOHN PEEL and BARBARA THOMPSON 143 pp. $€ 3.00$ (U.S.\$8.50)}

List of contents and authors:

General Introduction by P. R. Cox. Coordination of the Reproductive Processes by G. W. Harris. Environmental Influences on Human Fertility by Alan S. Parkes. Biosocial Aspects of Multiple Births by P. P. S. Nylander. Human Fertility in Global Perspective by D. M. Potts. Cultural Explanations of Fertility Differences by J. Clyde Mitchell. Some Social Determinants of Recent Trends in British Fertility by Joan Busfield and Geoffrey Hawthorn. Family Structure and Educational Achievement by David Oldman, Bill Bytheway and Gordon Horobin. The Galton Lecture 1970: The Otstetrician and Society by Sir Dugald Baird. Domiciliary Family Planning Services: A Reappraisal by P. F. Selman. The Unwanted Pregnancy by Peter Diggory. Sex Education in Schools-Why and How? by K. John Dennis.

\section{SUPPLEMENT No. 4}

\section{FERTILITY REGULATION DURING HUMAN LACTATION}

Edited by A. S. PARKES, A. M. THOMSON, M. POTTS and M. A. HERBERTSON 211 pages $€ 10.00$ (U.S. $\$ 20.00$ ) hardback

\section{£8.50 (U.S.\$17.00) paperback}

List of contents and authors:

Participants. Opening of Workshop, Alan S. Parkes and Angus M. Thomson.

LACTATIONAL INFERTILITY: Physiology of lactation by A. S. MeNeilly. Neuroendocrine control of lactational infertility by John E. Tyson. The chance of conception during lactation by J. K. van Ginneken. BREAST-FEEDING: Social ând behavioural aspects of breast-feeding by M. Carballo. Biosocial advantages of an adequate birth interval by D. Morley. WHO Collaborative studies on breast-feeding by M. Carballo. LACTATION AND CONTRACEPTION: Interactions of contraception and breast-feeding in developing countries by W. H. Mosley, T. Osteria and S. L. Huffman. Studies on lactation and contraception in WHO's research programme by $\mathbf{R}$. M. Bernard.

STEROID CONTRACEPTION DURING LACTATION: Effect of oral contraceptives on the production and composition of human milk by A. N. Gupta, V. S. Mathur and S. K. Garg. Effects of some progestational steroids on lactation by M. H. H. Badraoui, G. Fawzi and F. Hefnawi. Side effects of steroid contraception by J. J. Gellén. Appearance of contraceptive steroids in human milk: effects on the child by J. K. Harfouche. PROBLEMS AND PROSPECTS: Do non-steroidal methods of contraception affect lactation? by Angus $\mathbf{M}$. Thomson. Baby foods - a role for industry? by D. Morley. Professional attitudes to breast-feeding by Ursula Liebrich. Demographic considerations by R. H. Gray. Research requirements by Malcolm Potts.

\section{SUPPLEMENT No. 5}

\section{FERTILITY IN ADOLESCENCE}

Edited by A. S. PARKES, R. V. SHORT, M. POTTS and M. A. HERBERTSON 211 pages $\mathrm{f} 12.50$ (US\$27.00) hardback

List of contents and authors:

Participants. Opening of Workshop. F. T. Sai.

GENITAL MATURATION: Genital in relation to somatic maturation by Frank Falkner. Time of onset of sperm production in boys by D. W. Richardson and R. V. Short. The ovary learns to ovulate by B. Lunenfeld, Z. Kraiem, A. Eshkol and I. Werner-Zodrow. Oestrogen and pregnanediol excretion through childhood, menarche and first ovulation by J. R. Brown, Patricia Harrisson and Margery A. Smith. TEENAGE PREGNANCY-INCIDENCE AND OUTCOME: Teenage pregnancy in England and Wales: some demographic and medico-social aspects by D. Rothman and P. Capell. The incidence and outcome of adolescent pregnancy in the United States by Joy G. Dryfoos. Pregnancy in adolescence: incidence and outcome in European countries by J. P. Deschamps and G. Valantin. Teenage pregnancy in developing countries by Lars Engstrom.

CONTRACEPTION AND ABORTION IN TEENAGERS: Contraception in adolescence-a review of the literature by Elsa Ryde Blomqvist. Acceptability and use-effectiveness of contraception for teenagers by Ruth Coles. Social and emotional aspects of pregnancy in teenagers by Pauline Crabbe.

ADOLESCENT SEXUALITY: Law, policy and adolescent sexuality by John M. Paxman. Socio-cultural aspects of age at marriage in the Middle East by Sattareh Farman-Farmaian. Some psychosexual problems of Asian adolescents by N. Kodagoda. Social and psychosexual problems of African adolescents by F. A. Sai. Adolescent sexuality — changing needs and values by Manuel Carballo. Closing of Workshop. R. V. Short 